\title{
Perspectives
}

\section{A Rationale for L1-to-L2 Literary Translation in College EFL Instruction}

\section{James W. Porcaro \\ Toyama University of International Studies}

Translation is a much-neglected area of EFL instruction, long shunned by many within the field of ELT. However, there are various kinds of translation and some can be very effective pedagogical instruments. A course in Japanese-toEnglish literary translation in EFL college programs in Japan has demonstrated its effectiveness in developing students' written expression in English. A rationale for this approach lies within the relationships across languages and across the modalities of $\mathrm{L} 1$ reading and $\mathrm{L} 2$ writing. This needs to be unified with an understanding of practice, in particular, teacher-student conferencing and peer collaboration. It is hoped that a synergism ${ }^{t}$ will emerge from further study and research on this topic along with more teachers assuming positive views toward this kind of translation instruction and attempting to undertake it in their classrooms.

翻訳はEFLの授業で非常に軽視され，ELTの分野の多くの教師によって長ら く避けられてきた領域である。しかし、翻訳には様々な種類があり、使い方に よっては大変効果的な教育手段になりうるものである。日本語から英語への文 学作品の翻訳演習を行う日本の大学でのある講座は、翻訳演習が学習者の英語 での文章表現力を養うのに有効であることを既に示している。このような教授 法の理論的根拠は、異なった言語の間の相互関連性およひ、、第 1 言語の読解力 と第 2 言語の文章表現力の間の相互関連性に存するものであり，実践方法の理 解、とりむけ教師と学習者の間での相談や学習者同士の共同作業のやり方につ いての理解が統合される必要がある。このテーマについてのさらなる研究の進 展と、この種の翻訳演習の授業に肯定的な見解を持つより多くの教師による教 室での寒践が相乗効果をあげることが望まれる。

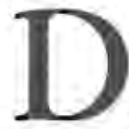

iscussion of appropriate and effective uses of students' first language (L1) in English as a foreign language (EFL) instruction, including observations of the benefits of L1 use in the L2 
(second language) writing process, has been going on for some time in the literature of English language teaching (ELT). Yet it seems when language teachers hear the word translation in this context, most recoil and think that it is an outdated and ineffective way of teaching. Howatt (1991) has noted that the practice of translation has been denounced so strongly for so long that many teachers still proscribe its use in language learning as a matter of principle. Discussion about how translation might be effectively employed as a teaching methodology in language classes barely registers a blip as one scans the professional field of ELT publications and conference presentations.

Translation is generally associated with the grammar-translation method, an application of the traditional approach used to teach the classical languages of Latin and Greek, in which instruction is provided almost entirely in the students' native language and the focus is on the explanation of grammar rules, the memorization of native language equivalents of target language vocabulary, and the translation of reading passages in the target language that are selected without particular regard to content or level of difficulty into the native language (see Howatt, 1991). This method is believed by advocates and practitioners of communicative approaches to hinder severely the successful acquisition of functional use of the target language (e.g., see Brown, 1994; Rivers, 1981).

It is important to recognize, however, that there are various types of translation and a number of ways in which it can be utilized as a very productive pedagogic device in language classes. Widdowson (1979) has affirmed that in some circumstances certain kinds of translation indeed may provide the most effective means of learning. From 1990 to 2000, I taught a course in Japanese-to-English literary translation, first in the intensive English program of a two-year college and later in the EFL program of a university. The Japanese students' proficiency levels were generally from lower to upper intermediate. Although lacking the empirical evidence of a controlled comparative study, my direct experience with the work of more than 150 students has provided compelling support for the assertion that the English translation texts that they produced often demonstrated a higher order of language structure and expression than writing products generated from standard assignments in composition and academic writing courses that were also part of the curriculum for these students.

At the same time, there is a broad range of language skills involved in the process of translation. Malmkjaer (1998) has noted that a good deal of reading, writing, speaking, and listening is required for the production of an acceptable translation. The four language skills are inte- 
gral components of the process and language students who are translating receive considerable practice with them. The involvement of speaking and listening will become clear in the discussion of teacherstudent conferencing and peer collaboration.

This article does not at all contend that such a translation course by itself is sufficient to fully develop students' $L 2$ writing skills. Rather, it presents a basis for the argument that L1-to-L2 translation entails complex and multiple interrelationships between reading and writing, including an important relationship between L1 reading and L2 writing, which can effectively advance second language writing skills and proficiencies. The instructional methodology for the approach to Japanese-to-English literary translation that is discussed in this article has been presented in detail previously by Porcaro (1998), who gives titles and authors of many texts that were used successfully in the translation course. The summaries of the classroom methodology that follow are derived from that article.

\section{Reading/Writing Connections}

A number of studies have explored interlingual and intralingual reading and writing relationships, and reseatchers have considered the pedagogical implications of their findings. In a study of Chinese and Japanese students of English as a second language (ESL) at universities in the U.S., Carson, Carrell, Silberstein, Kroll, and Kuehn (1990) used writing prompts for essay samples and cloze passages in both the first languages and English in order to analyze second language literacy in terms of both interlingual transfer and intralingual input. They found that literacy skills can transfer across languages, but the pattern and strength of this transfer vary according to first language and educational background and expericnce. The results also indicated that reading ability transfers more easily from L1 to L2 than does writing ability, suggesting that $L 1$ reading skills can have some impact on L2 reading. However, the weak correlation between L1 and L2 writing for the Japanese students and the absence of a correlation for the Chinese learners suggested the possibility of very limited, if any, exploitation of L1 writing in ESL writing pedagogy. The authors concluded that L2 literacy development for adult ESL learners is a complex phenomenon involving multiple variables, and that particularly at higher levels of proficiency, intralingual input may be very important for L2 literacy skills development.

Underscoring the complexity of these relationships are the results of other studies of Japanese students that followed the work of Carson 
et al. (1990). In their examination of Japanese university students' English expository writing, Hirose and Sasaki (1994) investigated several factors that might have influenced the quality of the writing product. They found that L1 writing ability was highly correlated with L2 writing ability and formulated the hypothesis that "Japanese EFL students' composing competence (measured by the quality of L1 writing) and L2 proficiency both influence the quality of their L.2 writing" (p. 219). Kubota (1998) investigated rhetorical structures in Japanese L1 and English L2 essays. The findings of her study indicated that students who wrote well in Japanese could be encouraged to apply the L1 writing strategies that they used to ESL writing as well. On the other hand, those who wrote poorly in Japanese could be expected to need extensive training in how to organize ideas effectively for ESL writing.

Eisterhold (1990) highlights the enigmatic relationship between reading and writing using three models of the reading-writing connection. The directional hypothesis holds that "reading and writing share structural components such that the structure of whatever is acquired in one modality can then be applied in the other" (p. 89). But this transfer can proceed in only one direction, most commonly from reading to writing. The nondirectional hypothesis is an interactive model in which "reading and writing are said to derive from a single underlying proficiency, the common link being that of the cognitive process of constructing meaning" (p. 90), and transfer can occur in either direction. The bidirectional hypothesis claims that reading and writing are not only interactive, but interdependent as well, Gousseva (1998) succinctly applies the reading-writing connection to the language learning process, as follows:

The development of literacy involves development of writing and reading as conjoined activities with shared cognitive processes that shape each other, and are affected by (and affect) the context in which they occur. (unpaginated)

In the context of second/foreign language learning, Cummins (as cited in Eisterhold, 1990) claims "there is an underlying cognitive/academic proficiency that is common across languages that allows transfer of literacy-related skills across Ianguages" (p. 95). Eisterhold adds'

It appears that L1 literacy skills can transfer to the second language and are a factor in L2 literacy acquisition.... The general process of acquiring $\mathrm{L} 2$ writing and reading abilities appears...to be influenced by the transfer of L.1 literacy skills that affect the 
quality of L2 reading and writing quite apart from what can be learned from the second language itself. (p. 99)

\section{L1-to-L2 Translation}

The almost entirely neglected area of second language learning involving L1-to-L2 translation exposes a reading-writing connection hitherto unexamined, namely, the relationship across languages and across modalities of L1 reading and L2 writing. Rivers and Temperley (1978) have insightfully described the translation process that leads us into this area, as follows:

The production of an acceptable translation into English is [for students].... means for developing sensitivity to the meanings expressed in a stretch of discourse in one's own language and to the different linguistic mechanisms used by the two languages to convey these meanings, Students learn to translate ideas, not words. This type of exercise is, therefore, an analytic activity. Through a comparative examination of the syntactic and semantic systems of English and the native language and the cultural contexts in which they operate, students attempt to expand their own potential for expression in the English language. (p. 337)

There are, however, just a few disparate studies that have investigated the element of translation from $\mathrm{L} 1$ in relation to second language writing. Friedlander (1990), for example, reviewed a number of studies, which indicated that L1 writing strategies could positively affect L2 composing. He sought to identify the circumstances in which adult ESL writers' L1 could be more helpful than the $\mathrm{L} 2$ in recalling knowledge about a particular subject. His study of Chinese-speaking ESL students at a U.S. university confirmed his hypothesis that ESL writers would be able to plan more effectively and write better English L2 texts when they could plan for their writing in the language of the topic knowledge and then translate into English. That is to say, students who planned in Chinese for the given topic that related to a Chinese experience generated English essays that were superior in quality to those written by students who planned for that topic in English. This kind of task is a long way from literary translation, but perhaps the results of the study suggest the role played by schemata from student-translators' L1 background in their engagement with a literary text in the construction of meaning asd in the reconstruction into English of that 
text that in its essence is inseparable from its social and cultural origins.

Kobayashi and Rinnert (1992) compared compositions of the same students that resulted from two different writing processes. One was written directly in L2 English and the other was composed in the first language and then translated by the writer into L2 English. The subjects of the study were Japanese EFL students at a university in Japan. Although there are very important differences between translating a text one has written oneself and translating a given $\mathrm{L} 1$ text, the findings from the research should be considered. It was found that the students produced significantly better L2 English compositions, in terms of quality of content, organization, and style, by writing via translation (from Japanese) than by writing directly in L2, although the students in the low proficiency group in their study benefited more from translation than the students in the high proficiency group. Syntactic complexity was also greater in the translations, but there were more errors that interfered with intended meaning in the translations of the higher-level students than in their direct writing. Some of the implications of these findings relate to those drawn by Friedlander from his study. Kobayashi and Rinnert noted that the use of the first language especially by lower-level students might enable them to explore ideas fully within their own intellectual and cognitive boundaries. Thus, they could benefit from L1 use in this way, especially in the prewriting and planning stages. At the same time, they cautioned that the extensive use of translation of one's own L1 text hinders writing fluency and the development of other L2 writing skills. On the other hand, genuine translation from a given L1 text into L2 English can be an effective language learning methodology at all proficiency levels.

Uzawa (1996) has confirmed the fact of the scarcity of empirical data on translation in the framework of language learning. Her work was a comparative study of L1 writing, L2 writing, and translation processes. The subjects were Japanese ESL students studying at a Canadian college. The research design included think-aloud protocols, observational notes, a questionnaire, and interviews, in addition to the writing samples. The translation task (from L1 Japanese into L2 English) was from a magazine article and expository in nature, as were the topics for L1 and L2 writing. It was found that scores on language use were significantly higher in the translation task than in the L1 and L2 writing tasks, and students paid much attention to words in order to express in English the meaning of the Japanese text. This would seem to uphold the assertion of a supportive relationship between L1 reading and L2 writing through the translation process. Uzawa re- 
marked, however, "the participants were freed from the cognitive activities of generating and organizing ideas, and [thus] were able to concentrate on linguistic activities" (p, 288). This seems to ignore the considerable cognitive transaction with the given L1 text in the construction of meaning that is an integral element of the process of translation and the $\mathrm{L} 1$ reading/L2 writing connection. Nevertheless, she noted that those students in her study whose scores were relatively high in the L2 writing task responded that translation is more helpful for language use than L2 writing. She concluded that translation tasks may be useful for second language learning in that the process requires learners to use words, expressions, grammar, and syntax that are a little beyond their present level.

\section{L1 Reading/L2 Writing Connection}

We need, then, to pursue further these aspects of the integration of reading and writing in the process of L1-to-L2 translation. First, on the nature of the processes of reading and writing, Zamel (1992) has stated:

It has become commonplace to characterize the act of writing as a meaning making, purposeful, evolving, recursive, dialogic, tentative, fluid, exploratory process. Recent research and theory in reading have shown us that these terms can be applied as well to the act of reading. (p, 463)

At the same time, meaning is culture-specific. Readers bring their own schemata to their transaction with a text in order to construct meaning. When reading, Goodman (1994) has noted:

The reader [constructs] a text parallel and closely related to the published text. It stays the same yet is a different text for each reader. The reader's text involves inferences, references, and coreferences based on schemata that the reader brings to the transaction. And it is this reader's text that the reader comprehends and on which any later retelling is based. (p. 148)

Remarkably, this description relates almost literally to the process undertaken in translation as well. The task of translation involves students first in an understanding of the $\mathrm{L} 1$ text, and literary text in particular is inseparable from its social and cultural origins. Brannen (1997) has made the point as follows: 
All translation is the translation of culture, whether considered narrowly as the transfer of meaning expressed in one language into equivalent expressions in another language, or broadly on a socio-semiotic scale embracing a range of semiotic systems. (p. 169)

Students, therefore, consciously apply the schemata from their Japanese background and go on to reconstruct ("retell") the L1 text in writing in English. In the process of translating a literary text, students attempt to deepen their understanding of its social and cultural background, and to reexamine its essence so that they can aptly communicate it in English. They are involved in a transaction with the L1 text in order to construct an equivalent L2 English written text that "reproduce[s] the greatest possible degree of the meaning of the original [text] ${ }^{n}$ (Newmark, 1988a, p. 66). This is a unique application of the interrelationship of the processes of reading and writing, in which the L1 literary text provides "comprehensible input" (Krashen, 1987) for writing. The resultant English translation text contributes "comprehensible input" not only back to the L1 text but also to the students' reading of their own $L 2$ products and the published professional translation(s) that are later read and compared with the texts that they themselves have constructed from the same L1 source text. Studenttranslators are involved in acts of reading and writing, as described above by Zamel, with continual re-reading of the literary text along with a writing process that includes drafting, consulting dictionaries, reflecting, conferring, collaborating, revising, and editing that is described in detail by Porcaro (1998) and discussed below.

\section{L1 Literary Texts and Methodology}

Very carefully selected extracts from works of L1 literature for translation offer Japanese college and university EFL students a unique opportunity to explore the dimensions of both languages and to develop written expression in English that is of a nature and quality both different from and beyond the products of standard composition in the second language. Duff (1989) has commented on the value of translation:

Translation develops three qualities essential to all language learning: flexibility, accuracy, and clarity. It trains the learner to search (flexibility) for the most appropriate words (accuracy) to convey what is meant (clarity). This combination of freedom and constraint allows the students to contribute their own thoughts to a discussion that has a clear focus-the text. (p. 7) 
The text requires that "students consider various aspects of meaning they have extracted and rethink it in terms of the target language so that as little is added and as little is lost as possible" (Rivers \& Temperley, 1978, p. 329). They need to think "from the meaning to the words and not the other way round" (Duff, 1981, p. 22), and let thought shape language, not language structure thought (p. 20). As Newmark (1988a) has noted, accuracy in a communicative translation is basically lexical, and thus students must engage in a mental struggle to choose the words for their translations. The grammar can be treated more flexibly, so they must undertake transpositions and shifts of structures and changes of word order over a wide range and depth in order to produce as fluent and as economical a translation as they can. Yet meaning is shaped by sentence structure as well. These language choices are determined by the needs of the target language as "language structures reality" (Duff, 1981, p. 111).

\section{Text Selection}

The rationale for using LI (Japanese) literature is that it more suitably elicits the kind of language encounter that has been described in this article as compared with essays or newspaper and magazine articles, for example. In my teaching experience literature is far more interesting to the students. It gives them a genuine sense of purpose and achievement to render well a work by a renowned author and to be able to compare their work with professional translations, and it enhances their appreciation and enjoyment of good literature in itself.

The teacher's wide reading of Li literature, in the original or good translation, is important for choosing texts that are most suitable for students and the teacher him/herself, and for accumulating a repertoire of texts from which an imaginative and effective syllabus can be developed. There is a very wide range of Japanese literary texts at various levels of difficulty that can be used. Short stories of moderate length are very convenient to work with and excerpts from novels, as well as different forms of poetry, may be chosen and used successfully.

The determination of appropriate extracts from the literary works is absolutely critical. I generally use a few continuous pages from stories: a scene with the principal characters, a highlight or pivot of the story, or a scene representative of the story as a whole. A combination of narrative and dialog, with minimal description, generally works best, heeding the observation that "narrative, a sequence of events, is likely to be neater and closer to translate than description, which requires the mental perception of adjectives and images" (Newmark, 1988b, p. 
50). The teacher needs to consider with much care the level of language structure and vocabulary that will be required to render the L1 text into the L2. Consultation with a native L1 speaker with background in the L1 literature, high proficiency in the L2, and ideally some experience in translation, can be very instructive.

\section{Teaching Translation in EFL}

As Newmark (1991) has pointed out, teaching transiation within language teaching needs to be distinguished from teaching translation. The teacher for such a course, or one using literary translation as a component in a general writing course, need not have a high command of the L1, nor be a literary scholar or translator, but certainly should have studied the language in some depth and acquired a good understanding of its basic structure and grammar, a functional base of vocabulary, and some reading ability. Ready and reliable access to an L1 consultant is quite important. At the same time, the teacher should be familiar with some fundamental principles and practices of translation itself, such as the principles of equivalent effect and equivalent frequency of usage, and the treatment of the repetition of words, "empty words," collocations, metaphors, cultural words and allusions, and ambiguity. While endorsing the role of translation as a valuable resource in the foreign language classroom, Stibbard (1998) has cautioned:

[S] uch translation must be grounded in a sound understanding of the principles that should underline all translation activity. If there is no such understanding of the many factors that influence the translation process, then translation will not be a useful pedagogical tool (p. 69)

Research, consultation, careful planning and preparation, and detailed attention to students' work and individual needs make possible the literary translation instruction discussed in the present article.

\section{Beginning the Translation Process}

After the teacher has introduced the literary work and the author to the class, students are assigned the LI (Japanese) text to read carefully several times so that they understand the story and the particular scene that they will translate, as well as to examine elements such as the structure, vocabulary, style, and tone of the piece. Further discussion of the content of the text and attention to particular translation prob- 
lems are taken up as students move through the translation process itself. This is a holistic approach in which students' work begins directly on the texts. Duff (1989) notes: "Translation, unfortunately, is something you learn only by doing"(p. 13).

Although literary translation methodology must focus on students' products, it should simultaneously accept the following affirmation by Stibbard (1998):

\begin{abstract}
Translation as a teaching activity should be concerned with the process and skill of translation and only with the end product in so far as it arises from sound skills development. The general student benefits from merely working toward solutions, understanding the factors that determine decisions and from evaluating these decisions. The final product is for our purposes of less importance than the work that went into producing it, (p. 73)
\end{abstract}

\title{
Teacher-Student Conferencing
}

Students are assigned appropriate quantities of the L1 literary text to translate in draft form in approximately equal portions each week spent on the translation task. Having reviewed the drafts in students' notebooks in advance of the class meetings and made some editorial markings and comments, I have a brief conference in class with each student on his/her draft while the others are involved in peer collaboration. Usually a few points are treated with the class together. The teacher's response to students' drafts and the conferencing are crucial parts of the translation writing process as the drafts always need a lot of further work, which, of course, is normal even for professional translators.

In reviewing students' drafts, the teacher may use a good published professional translation (sometimes two or three are available) as a guide along with the original L1 text. To understand how a teacher with limited L1 language proficiency can capably deal with the drafts, it is very important to understand that by this point in the instructional process he/she has already very carefully studied the assigned text in the manner that has been described, seen the drafts of all the students and often had the experience of using the text with past classes. That is, he/she has worked with as many as dozens of translations of the L1 text, and continues to review various points relevant to the translation with native L1 speakers as well as the current students.

In her study of teachers' responses to student writing in ESL instruc- 
tional settings, Zamel (1985) reported a number of implications that apply with as much or more relevance to teacher-student conferencing in L1-to-L2 translation instruction and its foundations. She advises that teachers respond to students' writing with 'text-specific strategies, directions, guidelines, and recommendations" and that "the concern [be] with the communicative effectiveness of the text" (p. 95). Translation conferencing focuses on elements such as word choice, accuracy, grammar, usage, word order, fluency, and style, but the essence of translation, as we have seen, is precisely its "communicative effectiveness" and this is the principal dimension of students' work that is the focus of conferencing. As Zamel urges teachers to help students understand, student-translators especially are sensitive to recognize the need to address meaning-level issues in the text first.

Zamel (1985) also tells us that students "must be made to understand that texts evolve, that revision is to be taken literally as a process of re-seeing one's text, and that this re-seeing is an integral and recursive aspect of writing" (p. 96). Throughout their work on a literary text, student-translators are involved in a continual process back and forth between re-reading the L 1 text and re-rcading and re-swriting their L2 translation texts. There is an inherent understanding of the necessity and value of this process. The instructor's facilitative assistance in conferencing with students reinforces the essential importance of continual clarification and exploration of both the L.1 literary text and the L2 translation text in order that meaning is clearly and accurately derived.

Zamel (1985) concludes with another statement particularly relevant to the relationship between student-translators and the native-speaker English teacher in an EFL setting:

To respond by participating in the making of meaning means that we no longer present ourselves as authorities but act instead as consultants, assistants, and facilitators, Thus, rather than making assumptions about the text, taking control of it, and offering judgmental commentary... we need to establish a collaborative relationship with our students, drawing attention to problems, offering alternatives, and suggesting possibilities. (pp. 96-97)

In the course of L1-to-L2 literary translation, this relationship quite naturally occurs in that students in fact are better placed than the teacher to make meaning from their transaction with the Ll text. Stu- 
dents are able to impart to the teacher meanings and deeper understanding of that text, while the teacher helps students to improve their L2 translations by pointing out the merits and insufficiencies therein and guiding them toward solutions to problems. In this way there is a unique form of two-way teaching and learning, a special sharing between the teacher and students with mutual acknowledgement and appreciation of both languages and cultures in a rewarding, interactive foreign language learning experience.

\section{Translation Processing}

Ivanova (1998) has reviewed several studies on translation processing and noted that research into language learners' translation strategies has found that students tend to engage primarily in lower-level processing during comprehension, translation production, and monitoring. This includes focusing on lexical and syntactic problems while disregarding text-level aspects. Seguinot (as cited in Ivanova, 1998) has suggested that potentially good translation students "work back and forth from the translation to the text.,.monitoring for meaning, meaning loss, for structure, cohesion, register, and style" and, thus, teaching is most effective when its focus is on improving revision strategies (p. 98). These remarks reinforce the necessity of effective teacher-student conferencing as discussed above and the conjunction of peer collaboration as outlined below in the methodology of L1-to-L2 literary translation for EFL students. These operations are essential in order to obtain positive outcomes from the translation process itself and high quality L2 translation products in the end.

Generally most problems with language use in translations into the second language are due to interference, which, according to Newmark (1991), occurs when any feature of the source language is carried over inappropriately into the target language text and falsifies or makes ambiguous the meaning of the text or violates usage. Malmkjaer (1998) has noted that even bilinguals experience interference in one way or another, and translation practice develops both awareness and control of interference.

\section{Peer Collaboration}

At each class meeting, students collaborate among themselves by comparing and discussing particular points of their drafts - especially those that the teacher has noted as needing correction or change - and alternatives and possible solutions to problems. Some research studies, however, have found peer collaboration problematic in ESL/EFL set- 
tings. For example, in a detailed study of peer response groups of students in an ESL freshman writing class at a U.S. university, Connor and Asenavage (1994) found that although students made many revisions in their essays, few were the result of direct peer group response. They stated that the small impact on revisions from peers' comments in the groups was disappointing and that they needed to reconsider some of the practices in their ESL writing program. On the other hand, in a study by Lockhart and $\mathrm{Ng}$ (1993), after undergoing carefully planned initial training sessions, Chinese students enrolled in an L2 writing class at a university in Hong Kong responded positively in a questionnaire to their participation in peer response groups. The researchers reported the following benefits of peer responses, which apply as well to the unique circumstances of the L1-to-L2 literary translation process:

It is useful in helping writers to receive feedback on ideational aspects of their writing.... It enables students to become more aware of the impression their writing creates in their readers.... It seems to improve the writing abilities of the reader... [and it enables students] to clarify positions and to negotiate between the meaning conveyed by the writers and the meaning perceived by the readers. (p. 23)

Peer collaboration on L.2 (English) translation drafts can be highly successful and provide the major input for the revision process that leads to successfully written final products. The teacher's review of each student's draft and the teacher-student conferences establish what aspects of the drafts need further work. Since students work from the same L1 text, each has a shared interest with all the other classmates in both giving and obtaining input to test solutions and resolve the translation problems each faces, though each student, of course, is responsible for producing in the end his/her own translation.

Peer collaboration supports and advances the reading-writing connections that have been discussed as the foundations for L1-to-L2 literary translation in EFL settings. Although Gousseva (1998) investigated an L1 university freshman composition class, her analysis of peer reviews also applies well and perhaps even more aptly to the translation setting. She has noted that the subprocesses of revision in writing and critical reading are highly related and derive from similar thought processes. Peer reviews, she believes, can be a powerful learning tool in this regard, providing students with valuable opportunities to develop critical reading skills. Indeed, in the process approach to L1-to-L2 trans- 
lation tasks advocated here, peer collaboration involves students in critical reading of others' L2 English texts as well as re-reading their own and the original L1 literary text from which all the drafts are derived. This critical reading is further applied later when they read published professional translations of the same L1 literary text that are evaluated and compared with their own. Even there they discover that these professional L2 translation texts are not flawless in terms of accuracy and construction of meaning. Finally, as Gousseva has pointed out, peer collaboration also increases students' motivation for writing; assists them in gaining confidence in their writing and in their ability to learn from one another and themselves; provides opportunity to develop metalanguage useful for thinking and talking about writing; and encourages an awareness of writing as decision making as they reflect on alternatives, make choices, and consider the reasons behind their choices.

\section{Concluding the Translation Process}

After each week's work of drafting, reviewing, conferencing, and collaborating on successive portions of the assigned text, students revise and edit their drafts. When work on the entire assigned text is completed, students submit final copies of their translations. These are evaluated holistically with careful attention to accuracy, fluency, and style. Grammar, syntax, and vocabulary use are also closely examined. I correct, change, and reconstruct elements of the text only where necessary, tampering as little as possible in order to maintain the integrity and individuality of each translation. Papers are returned to students with written comments and copies of published professional translation(s) of the literary text, Students are asked to examine and compare their own texts with the professional translation(s) alongside the original L1 text in order to see, consider, and discuss alternative ways to render parts of the original L1 literary text, as well as to identify flaws in accuracy and the construction of meaning in the professional translation(s). This work is discussed in the final class for the particular text and importantly adds further to the conviction students have already developed that translation is a process and may involve multiple interpretations as well as uncertainties. It instructs them to hold regard for the integrity of their own work. This brings closure to the translation task. 


\section{Conclusion and Research Recommendations}

This article has presented a rationale for instruction of L1 (Japanese)to-L2 (English) literary translation in college EFL settings to support the methodological approach described by Porcaro (1998). Theory and practice are interactive and interdependent. While theory informs practice, what works in practice must be incorporated with theory in the formulation of a unified and understandable approach to pedagogy that bears meaningful outcomes that advance the language development of foreign language learners.

This article has attempted to convey an understanding of the foundations that support the practice of one kind of translation that can be a very effective means of language learning. However, much further work in this area of instruction and learning needs to be done, including empirical research. Yet, one of the factors still limiting further studies is the fact that very few EFL teachers are involved in any instruction of this kind. It is hoped that a synergism will emerge in which more and more teachers assume positive views toward translation instruction and attempt to undertake it in their classrooms while research further explores and clarifies the issues involved and thereby strengthens its theoretical and methodological foundations.

Perhaps the most fundamental question needing empirical quantitative research regards the assertion in this paper that translation develops EFL learners' writing abilities in ways different from and beyond usual writing tasks. Specifically, does translation instruction from suitable L1 literary texts into L2 English raise the quality of second language writing of college EFL learners to any greater degree or in any different manner than the composition writing tasks that are completed directly in English in a general writing course? It must be implicit in an empirical investigation that integral to the translation task is the judicious selection of literary texts and the employment of the instructional/learning methodology of process writing that includes teacherstudent conferencing and peer collaboration as discussed in this paper. Within this research, the specific aspects of students' writing that may be affected need systematic investigation, as well as does the nature of the process inyolved in translation. For example, in looking into the translation strategies employed by students, the inclusion of think-aloud protocols, interviews, and observations in the research design may yield insightful results. The attitudes and perceptions of students in such a translation course gathered from questionnaires and interviews would be important to the research inquiry. One other factor that should not be overlooked is the effect of the enthusiasm and 
conviction of the teacher on the outcomes from such a course. The collective translation work of more than 150 students over a period of ten years, along with composition and academic writing coursework from a number of the same students for comparison, has provided me with convincing documentation of the effectiveness of translation instruction as described in this article and in Porcaro (1998) for foreign language acquisition and for the development of L 2 writing competence. Nevertheless, empirical evidence based on an appropriate research design will be needed to establish the legitimacy and effectiveness of this approach.

My experience has been that students find satisfaction, reward, enjoyment, and challenge in the task of L1 (Japanese)-to-L2 (English) literary translation. Students working with selected texts from a rich field of L1 literature in a translation writing process that includes teacherstudent conferencing and peer collaboration has generated remarkable English language products. (See the Appendix for a representative example.) The methodology, with an understanding of its foundations, needs to be appreciated and applied on a far greater scale in the world of EFL instruction.

\section{Acknowledgements}

The author would like to thank the anonymous reviewers for their valuable comments, the editor for his encouragement and support, Hideo Horibe for his many years of aid as a consultant on Japanese-to-English translation, and the unnamed student for permission to include her translation work.

James W. Porcaro is an associate professor at Toyama University of International Studies.

${ }^{1}$ Synergism, or synergistic effect, refers to the action of two different effects acting together to create a greater effect than the sum of the actions produced by each acting independently. 


\section{References}

Brannen, N. S. (1997). Translation: Where cultures meet: Translating J-E. Los Angeles: J-E Link, Inc.

Brown, H. D. (1994). Principles of language learning and teaching (3rd ed.). Englewood Cliffs, NJ: Prentice Hall Regents.

Carson, J. E., Carrell, P. L., Silberstein, S., Kroll, B., \& Kuehn, P. A. (1990). Reading-writing relationships in first and second language. TESOL Quarterly, 24 (2), 245-266.

Connor, U., \& Asenavage, K. (1994). Peer response groups in ESL classes: How much impact on revision? Journal of Second Language Writing, 3 (3), 257. 276 ,

Duff, A. (1981). The third language. Oxford: Pergamon Press.

Duff, A. (1989). Translation. Oxford: Oxford University Press.

Eisterhold, J. (1990). Reading-writing connections: Toward a description for second language learners. In B. Kroll (Ed.), Second language writing: Research insights for the classroom (pp. 88-101). Cambridge: Cambridge University Press.

Friedlander, A. (1990). Composing in English: Effects of a first language on writing in English as a second language. In B. Kroll (Ed.), Second language writing: Research insights for the classroom (pp. 109-125). Cambridge: Cambridge University Press.

Goodman, K. (1994). Reading, writing, and written texts: A transactional sociopsycholinguistic view. In R. Ruddell (Ed.), Theoretical models and processes in reading (pp. 141-180). Newark, DE: International Reading Association.

Gousseva, J. (1998). Literacy development through peer reviews in a freshman composition classroom. The Internet TESL Journal. Retrieved September 14 , 2000, from the World Wide Web; http://www.aitech.ac.jp/ iteslj/Articles/ Gousseva-Literacy.html

Hirose, K., \& Sasaki, M. (1994). Explanatory variables for Japanese students expository writing in English: An exploratory study. Journal of Second Language Writing, 3 (3), 203-229.

Howatt, A.P.R. (1991). A history of English language teaching. Oxford: Oxford University Press.

Ivanova, A. (1998). Educating the 'language elite': Teaching translation for translator training. In K. Malmkjaer (Ed.), Translation and language teaching: Language teaching and translation (pp. 91-109). Manchester, U.K.: St. Jerome.

Kobayashi, H., \& Rinnert, C. (1992). Effects of first language on second language writing: Translation versus direct composition. Language Learning, 42 (2), 183-215.

Krashen, S, (1987). Principles and practice in second language acquisition. New York: Prentice Hall International. 
Kubota, R. (1998). An investigation of L1-L2 transfer in writing among Japanese university students: Implications for contrastive analysis, Journal of Second Language Writing, 7 (1), 69-100.

Lockhart, C., \& Ng, P. (1993). How useful is peer response? Perspectives: Working papers of the Department of English, 5(1), 17-29. Hong Kong: City Polytechnic of Hong Kong.

Malmkjaer, K. (Ed.). (1998). Translation and language teaching: Language teaching and translation. Manchester, U.K.: St. Jerome Publishing.

Newmark, P. (1988a). Approaches to translation. London: Prentice Hall.

Newmark, P. (1988b). A texzbook of translation. London: Prentice Hall.

Newmark, P. (1991). About translation. Clevedon: Multilingual Matters Ltd.

Porcaro, J. (1998). Japanese literary translation in an English language program. The Language Teacher, 22 (12), 5-9.

Rivers, W.M. (1981). Teaching foreign language skills (2nd ed.), Chicago: University of Chicago Press.

Rivers, W. M., \& Temperley, M. S. (1978). A practical guide to the teaching of English as a second or foreign language. Oxford: Oxford University Press.

Stibbard, R. (1998). The principled use of translation in foreign language teaching. In K. Malmkjaer (Ed.), Translation and language teaching: Language teaching and translation (pp. 69-76). Manchester, U.K.: St. Jerome.

Uzawa, K. (1996). Second language leamers' process of L1 writing, L2 writing, and translation from $\mathrm{Ll}$ into L2, Joumal of Second Language Writing, 5 (3), 271-294.

Widdowson, H. G. (1979), Explorations in applied linguistics, Oxford: Oxford University Press.

Zamel, V. (1985). Responding to student writing. TESOL Quarterly, 19 (1), 79 101.

Zamel, V. (1992). Writing one's way into reading. TESOL Quarterly, 26 (3), 463-485.

(Received January 23, 2001 ; revised June 4, 2001) 


\section{Appendix}

Following is the final copy of a translation of the delicate and challenging text of the short story, Amagasa, by Yasunari Kawabata, written by a second-year university student in the translation course described in this article. The student's errors remain intact.

\section{Umbrella}

It was a spring rain, like a mist, which didn't get one wet, but somehow dampened the skin. The girl who rushed outside noticed the rain for the first time. "It's raining?"

The boy had opened his umbrella to cover his shyness as he passed in front of the shop where the girl was sitting rather than to protect himself from the rain.

But the boy held the umbrella over the girl in silence. She came under his umbrella in only her one shoulder. Though he was getting wet, he couldn't come closer to her and ask her to come in. While she wanted to hold the handle of the umbrella with him, she looked as if she was about to get away from his umbrella.

They went into a photo shop. His father, who was a government official, planned to transfer far away. This was a farewell photograph.

"Please sit side by side over there." The photographer pointed to a sofa, but the boy couldn't sit with her side by side. The boy stood behind the girl and his finger, which he put on the sofa, touched her haori lightly because he wanted to believe that their bodies were somewhere connected. It was the first time he touched her body. His finger felt her faint temperature and he felt a warmch as if he hugged her naked body.

As long as he lived, whenever he looked at this photograph, he would remember her body temperature.

"May I take another photograph? Sitting side by side. I want to take the upper half of your bodies."

The boy only nodded and whispered to her. "Your bair?"

The girl looked up at the boy, blushed, and then ran to the makeup room gently like a child with her eyes shining with bright joy.

When she had seen him passing in front of the shop, she had rushed outside and had had no time to arrange her hair. She always was worried about her disheveled hair that looked as if she had just taken off a bathing cap. But she was a shy girl who couldn't do up her hair in front of a man. The boy also had thought that what he had told her to do up her hair would have embarrassed her. 
The brightness that she went to the makeup room brightened him also. With this brightness, the boy and the girl sat close together on the sofa as a natural act.

As the boy was going out of the photo shop, he looked for his umbrella. As he looked casually, he noticed that the girl, who had gone out before him, had brought the umbrella and stood outside. She didn't realize that she had brought his umbrella and gone out until she was seen by him. And then she was surprised. With her casual behavior, might she have indicated that she felt that she was his?

The boy couldn't ask her to hold the umbrella. The girl also couldn't hand the umbrella to him. But it was a different way from which they had come to the photo shop. Suddenly they had become grown-ups, and they went back with a feeling like a married couple. That was caused only by a thing about an umbrella. 